\title{
Parametric sensitivity analysis of leachate transport simulations at landfills
}

\author{
E. Bou-Zeid ${ }^{\text {a }}$, M. El-Fadel ${ }^{\text {b,* }}$ \\ a Department of Geography and Environmental Engineering, Johns Hopkins University, 313 Ames Hall, \\ 3400 N. Charles Street, Baltimore, MD 21218, USA \\ ${ }^{\mathrm{b}}$ Department of Civil and Environmental Engineering, Faculty of Engineering and Architecture, \\ American University of Beirut, Bliss Street, P.O. Box 11-0236, Beirut, Lebanon
}

Accepted 2 March 2004

\begin{abstract}
This paper presents a case study in simulating leachate generation and transport at a 2000 ton/day landfill facility and assesses leachate migration away from the landfill in order to control associated environmental impacts, particularly on groundwater wells down gradient of the site. The site offers unique characteristics in that it is a former quarry converted to a landfill and is planned to have refuse depths that could reach $100 \mathrm{~m}$, making it one of the deepest in the world. Leachate quantity and potential percolation into the subsurface are estimated using the Hydrologic Evaluation of Landfill Performance (HELP) model. A three-dimensional subsurface model (PORFLOW) was adopted to simulate ground water flow and contaminant transport away from the site. A comprehensive sensitivity analysis to leachate transport control parameters was also conducted. Sensitivity analysis suggests that changes in partition coefficient, source strength, aquifer hydraulic conductivity, and dispersivity have the most significant impact on model output indicating that these parameters should be carefully selected when similar modeling studies are performed.
\end{abstract}

(c) 2004 Elsevier Ltd. All rights reserved.

\section{Introduction}

Incidents of groundwater contamination by landfill leachate have been widely reported since the early 1970 s (Albaiges et al., 1986; Dunlap et al., 1976; El-Fadel et al., 1997a; Garland and Mosher, 1975; MacFarlane et al., 1983; Malina et al., 1999; Reinhard et al., 1984; Zanoni, 1972). This created the need to understand the mechanisms that control leachate formation, quality, quantity, and most importantly migration characteristics with associated spatial and temporal variations during landfill operations and after closure.

Leachate discharged from landfills is the main route for the release of the organic and inorganic contaminants commonly encountered in the refuse. Knowledge of the moisture content and flux is necessary but not sufficient for predicting leachate quality. The under-

\footnotetext{
${ }^{*}$ Corresponding author. Tel.: +961-3-228-338; fax: +961-1-744-462.

E-mail address: mfadel@aub.edu.lb (M. El-Fadel).
}

standing of processes and factors controlling the release and mobility of contaminants in the solid, liquid, and gas phases within the landfill is essential. Transport processes in landfills are associated with a high degree of uncertainty. While these processes are individually well understood and can be simulated reasonably well in a laboratory setting, their occurrence and interaction in landfills are still not fully comprehended (El-Fadel et al., 1997b).

\section{Project description}

The landfill examined in this paper is located $16 \mathrm{~km}$ south of Beirut (Lebanon) and $4 \mathrm{~km}$ inland at an average altitude of $250 \mathrm{~m}$ above mean sea level. The landfill, once the site of an abandoned quarry, is planned for development over an area of 20-27 ha approximately, and receives 1700-2100 ton/day of waste generated from the Beirut area and its surroundings. The landfill will have an active life of 10 years and the final waste height 
Table 1

Areas and capacities of landfill cells

\begin{tabular}{lll}
\hline Cell & Area $\left(\mathrm{m}^{2}\right)$ & Expected waste capacities (ton) \\
\hline 1 & $75,000-77,800$ & $1,362,167-1,725,000$ \\
2 & $52,609-138,000$ & $928,108-5,580,000$ \\
3 & $63,800-124,000$ & $1,009,725-4,800,000$ \\
Total & $194,209-262,000^{\mathrm{a}}$ & $3,300,000-12,105,000$ \\
\hline
\end{tabular}

${ }^{\mathrm{a}}$ Total area is obtained by adding the areas of cells 2 and 3 only. Cell 1 will be covered with a liner diverting all infiltration to cells 2 and 3, hence waste placed on top of cell 1 , above this liner, is considered part of cells 2 or 3 . The final areas and waste quantities may vary.

may reach $100 \mathrm{~m}$, making it one of the deepest in the world. Long term monthly meteorological data were taken from the Beirut International Airport (BIA) and the American University of Beirut (AUB) weather monitoring stations located within 15 and $20 \mathrm{~km}$ from the site, respectively. Total annual precipitation was 760 $\mathrm{mm} /$ year with average temperature, wind, and humidity of $21{ }^{\circ} \mathrm{C}, 4 \mathrm{~m} / \mathrm{s}$, and $63 \%$, respectively.

Following its collection, the waste is transported into a sorting and processing facility where bulky or large items (such as cardboards, PVC plastic containers, etc.), the recyclable waste fraction composed of glass, metals, etc., and a fraction of compostable organic food waste are removed. After the sorting process, the waste is compacted under a 290 bar pressure into bales $(\sim 1.1 \times \sim 1.1 \times \sim 1.5 \mathrm{~m})$ prior to disposal into the landfill which consists of three cells with different areas and capacities (Table 1). The organic content of the waste is around $65 \%$. Detailed waste composition and site description are presented in El-Fadel et al. (2002).

\section{Modeling methodology}

Leachate migration assessment typically involves two steps. First, leachate generation and infiltration through the landfill liner is quantified, then the migration of contaminants is modeled or measured in the porous subsurface until the point of compliance (the point where pollution level is to be assessed). The theory and governing equations of flow and transport in porous media have been the subject of extensive work, particularly in the past two decades, in response to problems arising from subsurface contamination. Numerous analytical or numerical models have been developed to simulate leachate flow and transport in the subsurface (see reviews in El-Fadel et al., 1997b, and US EPA, 1993). All these models solve mass, momentum and heat transport equations; however, model capabilities and solution schemes may differ widely. In this study, the subsurface flow and transport model PORFLOW (Runchal and Sagar, 1998) was applied to the landfill site.

\section{Leachate generation}

The HELP model simulates hydrologic processes for a landfill, cover systems, and other solid waste containment facilities by performing daily, sequential water budget analysis using a quasi-two-dimensional deterministic approach (Schroeder et al., 1994). The model divides the landfill into layers and applies the water budget technique to predict leachate generation quantities. Flow velocities are computed to predict time of leachate appearance. Channeling effect is implicitly accounted for by the optional inclusion of a waste layer with low porosity, low field capacity and low wilting point. Geomembranes and clay barriers can also be simulated and the leakage through the liners calculated. Most internal and external processes influencing leachate volumes are modeled including: surface storage, snowmelt, runoff, infiltration, evapotranspiration, vegetative growth, soil moisture storage, lateral subsurface drainage, leachate recirculation, groundwater infiltration, unsaturated vertical drainage, and leakage through soil. It does not account for water produced during the initial aerobic decomposition phase of putrescibles; this phase is however short lived and the leachate generated through this process is not expected to be significant.

The HELP model was used to predict leachate generation and infiltration into the subsurface. Detailed simulations and sensitivity analysis were performed; however, in this paper, only the results that were used in subsurface transport simulations are presented. These results represent the baseline scenario likely to occur in view of the site characteristics. The inputs and details of this scenario are detailed in Table 2. The landfill life was divided into three periods. The first period spans the first three years of the operational life of the site when cell number 1 is open; this cell has a different configuration than the rest of the landfill and is expected to produce more infiltration. The second period extends between years 3 and 10; cells 2 and 3 are operational during that period while cell 1 is closed and capped. Fig. 1 is a cross sectional view of the landfill depicting the different layers in the three cells. The third period starts at year 10 when all cells are closed and the final cap of the landfill is installed. Figs. 2 and 3 present the simulated leachate generation and infiltration into the subsurface from the landfill for the three periods, respectively.

\section{Subsurface transport simulation}

\subsection{Model description}

PORFLOW is a three-dimensional numerical model for the analysis of flow, heat, and mass transport in porous and fractured media. The model simulates coupled transport processes under transient or steady-state con- 
Table 2

HELP input parameters

\begin{tabular}{|c|c|}
\hline Parameter & Value \\
\hline \multicolumn{2}{|l|}{ Meteorological data } \\
\hline Daily precipitation, temperatures and solar radiation & Data from the American University of Beirut and the Beirut International Airport \\
\hline Average annual wind speed $(\mathrm{km} / \mathrm{h})$ & 14.5 \\
\hline Average quarterly relative humidity (\%) & Winter: 65 ; spring: 55 ; summer: 62 ; fall: 71 \\
\hline Maximum leaf area index & Closed covered landfill: 1.5 ; open uncovered landfill: 0.5 \\
\hline Evaporative zone depth & $30 \mathrm{~cm}$ (silty-sandy loams) \\
\hline \multicolumn{2}{|l|}{ Design data } \\
\hline Slope of drainage layer in leachate collection system $(\%)$ & Cell 1: 4; cells 2 and 3: 8 \\
\hline Area (ha) & Cell 1: 75; cell 2: 138 ; cell 3: 124 \\
\hline Drainage distance in leachate collection layer (m) & Pipe spacing 10 \\
\hline \multicolumn{2}{|l|}{ Top and bottom liners data } \\
\hline Cover slope $(\%)$ & 3 \\
\hline Drainage blanket slope $(\%)$ & 8 \\
\hline Drainage blanket conductivity $(\mathrm{cm} / \mathrm{s})$ & 0.3 \\
\hline Top soil conductivity $(\mathrm{cm} / \mathrm{s})$ & $0.37 \times 10^{-3}$ \\
\hline Liner equivalent diffusive $K(\mathrm{~cm} / \mathrm{s})$ & HDPE $0.2 \times 10^{-12}$; VFPE $0.4 \times 10^{-12}$ \\
\hline Geotextile thickness (mm) & 4.3 \\
\hline Geotextile in plane conductivity $(\mathrm{cm} / \mathrm{s})$ & 0.15 \\
\hline Cover geosynthetic drain conductivity $(\mathrm{cm} / \mathrm{s})$ & 5 \\
\hline Initial soil moisture content $(\% \mathrm{vol} / \mathrm{vol})$ & 0.8 field capacity \\
\hline Protective sand layer conductivity $(\mathrm{cm} / \mathrm{s})$ & $5.8 \times 10^{-3}$ \\
\hline Thickness of composite bottom liner (mm) & Geomembrane: 2; GCL: 6 \\
\hline GCL conductivity $(\mathrm{cm} / \mathrm{s})$ & $3 \times 10^{-9}$ \\
\hline VFPE geomembrane placement quality & Excellent \\
\hline VFPE geomembrane pinholes (\#/ha) & 2 \\
\hline VFPE geomembrane installation defects (\#/ha) & 10 \\
\hline HDPE geomembrane pinholes $(\# /$ ha) & Cell 1: 6; cells 2 and 3: 3 \\
\hline HDPE geomembrane installation defects (\#/ha) & Cell 1: 20; cells 2 and 3: 12 \\
\hline HDPE geomembrane placement quality & Cell 1: good; cells 2 and 3: excellent \\
\hline \multicolumn{2}{|l|}{ Waste characteristics (from calibration run) } \\
\hline Porosity (vol/vol) & 0.62 \\
\hline Field capacity (vol/vol) & 0.30 \\
\hline Wilting point (vol/vol) & 0.08 \\
\hline Initial moisture content (vol/vol) & 0.32 \\
\hline Saturated hydraulic conductivity $(\mathrm{cm} / \mathrm{s})$ & $3 \times 10^{-4}$ \\
\hline Initial MC of waste (vol/vol) & 0.32 \\
\hline
\end{tabular}

ditions using Cartesian or cylindrical coordinate systems. It can simulate confined or unconfined, isotropic or anisotropic, homogeneous or heterogeneous aquifers, fully or partially saturated media, single or multi-phase systems, and phase change (liquid-gas or solid-liquid). PORFLOW can also simulate discrete fractures in the porous medium or different regions (with different properties) within the solution domain (Runchal and Sagar, 1998).

\subsection{Modeling domain}

The geologic formations at the site date back to the cretaceous age. They consist of weathered carbonaceous rocks including marls, marly limestones, dolomitic limestones, fossiliferous limestones and occasional sandstones. Perched groundwater was located beneath the site at depths as low as $15 \mathrm{~m}$ below ground level; however, the main groundwater table lies at around $220 \mathrm{~m}$ below ground level, i.e., around $20-30 \mathrm{~m}$ above sea level. The general groundwater flow direction is westward towards the Mediterranean Sea with an approximate gradient of 0.05 . This indicates that locations that might be adversely affected by the landfilling activity include water wells along the flow path from the landfill to the seashore. The nearest population center to the disposal site is located $2.5 \mathrm{~km}$ downgradient. Fig. 4 presents a general schematic view of the simulated domain.

\subsection{Modeling process, input data, and boundary condi- tions}

The selection of the contaminants to be modeled was based on the corresponding concentrations in site-specific leachate samples, susceptibility to natural attenuation, and drinking water standards. An initial screening was conducted assuming no attenuation in the unsaturated zone. The screening revealed that Kjeldahl 


\begin{tabular}{|c|c|}
\hline \multicolumn{2}{|c|}{ Vegetation } \\
\hline Soil + Compost & $200 \mathrm{~mm}, 1 / 4$ slope \\
\hline Soil & $800 \mathrm{~mm}$ \\
\hline Geosynthetic drain & $11 \mathrm{~mm}$ \\
\hline VFPE geomembran & $2 \mathrm{~mm}$ \\
\hline
\end{tabular}

Cell 1

Waste layers

$80 \mathrm{~m}$ average

\begin{tabular}{lc}
\hline Darinage blanket & $500 \mathrm{~mm}$ basalt \\
\hline Geotextile & $4.3 \mathrm{~mm}$ \\
\hline Sand protection layer & $150 \mathrm{~mm}$ \\
\hline Geotextile & $4.3 \mathrm{~mm}$ \\
\hline Geomembrane & $2 \mathrm{~mm}$ \\
\hline Geosynthetic clay line & $50 \mathrm{~mm}$ \\
\hline \multicolumn{2}{c}{ Subgrade } \\
\hline
\end{tabular}

Vegetation

\begin{tabular}{l}
\hline Soil + Compost $200 \mathrm{~mm}, 1 / 4$ slope \\
\hline Soil $\quad 800 \mathrm{~mm}$ \\
\hline Geosynthetic drain $11 \mathrm{~mm}$ \\
\hline VFPE geomembrane $2 \mathrm{~mm}$
\end{tabular}

Regulating soil layer $500 \mathrm{~mm}, 1 / 4$ slope

Cell 2 waste layers Cell 3 waste layers \begin{tabular}{l|r}
$40 \mathrm{~m}$ average & $40 \mathrm{~m}$ average \\
\hline
\end{tabular}

Drainage blanket

\begin{tabular}{ll} 
& $500 \mathrm{~mm}$ basalt, $1 / 6$ slope \\
\hline Geotextile & $4.3 \mathrm{~mm}$
\end{tabular}

Sand protection layer $150 \mathrm{~mm}$

Geotextile $4.3 \mathrm{~mm}$

VFPE geomembrane $2 \mathrm{~mm}$

Geotextile $4.3 \mathrm{~mm}$

Sand protection layer $150 \mathrm{~mm}$

Regulating layer $500 \mathrm{~mm}$

Waste layers $\quad 40 \mathrm{~m}$ average

Darinage blanket $450 \mathrm{~mm}$ basalt

Geotextile $\quad 4.3 \mathrm{~mm}$

Sand protection layer $75 \mathrm{~mm}$

Geotextile $\quad 4.3 \mathrm{~mm}$

2 Geomembranes $2 \mathrm{~mm}+2 \mathrm{~mm}$

Geotextile $\quad 4.3 \mathrm{~mm}$

Graded sand $\quad 50 \mathrm{~mm}$

Subgrade

Fig. 1. Cross sectional view of the landfill.

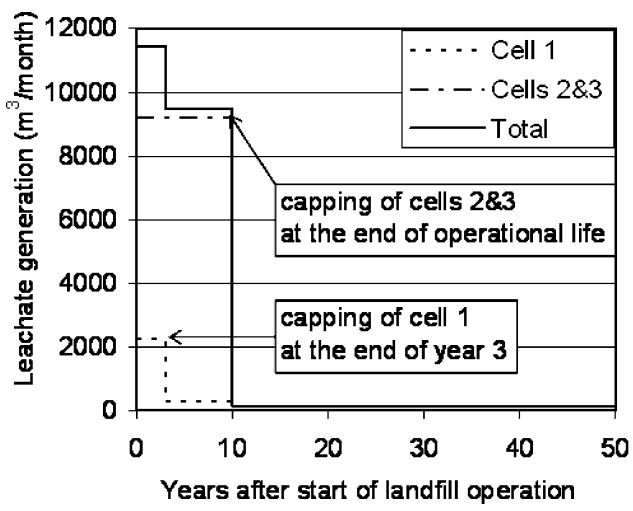

Fig. 2. Simulated leachate generation.

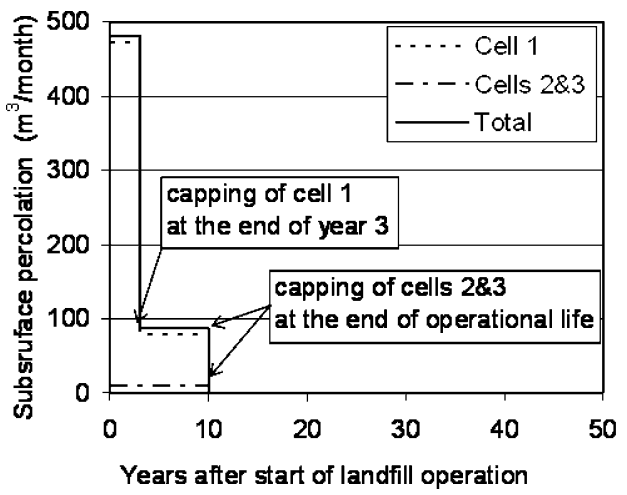

Fig. 3. Simulated subsurface infiltration.

Nitrogen $(\mathrm{K}-\mathrm{N})$, Manganese $(\mathrm{Mn})$, and Iron $(\mathrm{Fe})$ would be the most critical indicators. Kjeldahl-N was retained as the main indicator since it is less affected by attenu-

ation and retardation mechanisms than the other indicators and its concentration in the leachate remains relatively high (Kruempelbeck and Ehrig, 1999). Note that the Lebanese drinking water standards indicate a maximum allowable concentration of Kjeldahl-N of $1 \mathrm{mg} / \mathrm{l}$. The trends of the parametric sensitivity analysis for Kjeldahl-N should be valid for other pollutants.

\subsubsection{The unsaturated zone}

The flow and attenuation in the unsaturated zone are complex due to the heterogeneity of the topsoil and unsaturated rock zone beneath the landfill. Hence, this region was modeled as a control volume with a constant leachate breakthrough time. Flow was assumed to be one-dimensional.

The rock beneath the site contains extensive fracturing and faulting, and the connectivity and influence of these networks on infiltration time is difficult to establish with a reasonable degree of scientific certainty. If the rock beneath the site features a network of connected fractures, the breakthrough time may be reduced to just a few days. To account for this possibility and to present a worst case scenario, chemical attenuation in the unsaturated zone was neglected. Therefore, all leachate and contaminants infiltrating to the subsurface are assumed to reach the groundwater table after the breakthrough time.

\subsubsection{The saturated zone}

The unconfined aquifer, which has an average thickness of $120 \mathrm{~m}$ approximately, is underlain by an aquiclude that forms a no-flow boundary condition for water and contaminants. The input parameters for the baseline scenario are summarized in Table 3 .

Leachate flow rate through the landfill base becomes subsurface infiltration. Simulated subsurface infiltration decreases with capping of landfill cells (Fig. 3). An initial Kjeldahl-N concentration of $2500 \mathrm{mg} / \mathrm{l}$ in the subsurface infiltration is taken from monitoring data at the site. Concentrations are assumed to decrease to reflect contaminant attenuation in the landfill (Table 4).

The model-generated grid consisted of 8064 elements. The $X$-axis is from the site towards the sea; the $Y$-axis is from the site northward; the $Z$-axis is from the bottom to the top of the aquifer. Elements are geometrically uniform in the $X$ and $Y$ directions while in the $Z$ direction they expand from the top to the bottom. The size of one element is $x=250 \mathrm{~m}, y=87.5 \mathrm{~m}, z_{\min }=1.31 \mathrm{~m}$, and $z_{\max }=30.98 \mathrm{~m}$. The bottom and the vertical sides parallel to the streamwise velocity are set as no-flow boundaries. The top and upstream sides are inlet boundaries (a special boundary condition featured in PORFLOW, where the model imposes a constant flow rate or a constant concentration for chemicals), while the downstream side is an outlet boundary (also a special boundary condition featured in PORFLOW, where the model assumes an open 


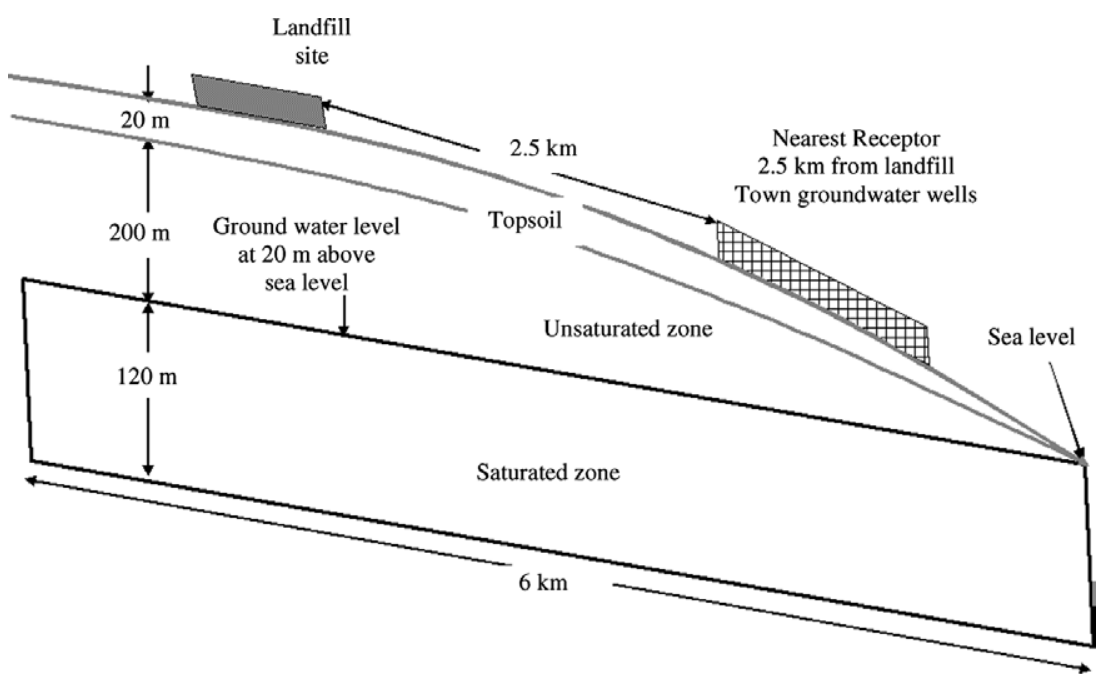

Fig. 4. Cross sectional view of simulated domain.

Table 3

PORFLOW input parameters for baseline scenario

\begin{tabular}{ll}
\hline Parameter & Base value \\
\hline Thickness $(\mathrm{m})$ & 120 \\
Saturated hydraulic conductivity $(\mathrm{m} / \mathrm{s})$ & $5 \times 10^{-4}$ \\
Gradient $(\mathrm{m} / \mathrm{m})$ & $30 / 6000$ \\
Total porosity $(\%)$ & 15 \\
Diffusive porosity $(\%)$ & 13 \\
Effective porosity $(\%)$ & 12 \\
Rock density $\left(\mathrm{kg} / \mathrm{m}^{3}\right)$ & 2000 \\
Tortuosity factor & 0.7 \\
Partition coefficient, $K_{\mathrm{d}}\left(\mathrm{m}^{3} / \mathrm{kg}\right)$ & $5 \times 10^{-3}$ \\
Diffusivity in water $\left(\mathrm{m}^{2} / \mathrm{year}\right)$ & 0.06 \\
Longitudinal dispersivity $\left(\mathrm{m}^{2} / \mathrm{year}\right)$ & 0.6 \\
Transverse dispersivity $\left(\mathrm{m}^{2} / \mathrm{year}\right)$ & 0.06 \\
Background contaminant level $\left(\mathrm{kg} / \mathrm{m}^{3}\right)$ & $0(\mathrm{no}$ upstream pollution is \\
& assumed) \\
Water temperature $\left({ }^{\circ} \mathrm{C}\right)(\mathrm{used}$ to set & 20 \\
density and viscosity) & \\
\hline
\end{tabular}

Table 4

Assumed variation of leachate source strength with time

\begin{tabular}{lll}
\hline Time (years) & Flow (m/year) & Kjeldahl-N concentration $(\mathrm{mg} / \mathrm{l})$ \\
\hline $0-3$ & 0.022 & 2500 \\
$3-10$ & 0.01 & 1500 \\
$10+$ & 0.005 & 1000 \\
\hline
\end{tabular}

boundary and computes the gradient at the boundary from values inside the domain).

\section{Model simulation results}

Two baseline simulations, one without and the other with fractures, and a series of sensitivity analysis simulations were conducted. The latter included variations in model parameters such as hydraulic gradient, aquifer hydraulic conductivity, source strength, diffusivity, lon- gitudinal and transverse dispersivities, fracture width, fracture hydraulic conductivity, and partition coefficient.

\subsection{Unfractured modeling}

Concentration contours of the plume for the base unfractured scenario indicate that peak concentrations occur $0-2 \mathrm{~m}$ below the water table. Fig. 5 illustrates concentration distribution contours 25,50 , and 75 years after the leachate reaches the ground water table. The profiles are average concentrations at a plane $2 \mathrm{~m}$ below the surface of the aquifer. Note that the contour for the drinking water standard is far from the receptor location. This indicates that, for the base scenario, the potential contamination is confined within several hundred meters of the landfill boundary.

\subsection{Fracture modeling}

While the parameters used for the base scenario are rather conservative, they assume a porous medium with no fractures; however, the rock layers beneath the landfill may have considerable networks of fractures. The potential effect of such networks was assessed by assuming one major fracture in the $X Z$ plane, i.e., parallel to the groundwater flow. The fracture was assumed to run directly under the landfill and extend horizontally to the sea and vertically to the aquiclude. The fracture width was taken as $10 \mathrm{~cm}$ and the hydraulic conductivity was set to 100 times that of the aquifer. The tortuosity factor was set to 1 , the porosity to $100 \%$, and the partition coefficient to zero. As mentioned earlier, in reality, this fracture represents a network of connected fractures rather than one major fracture.

Fig. 6 presents Kjeldahl-N concentration plume $2 \mathrm{~m}$ below groundwater table. The concentration at the receptor location was still far below local drinking water 

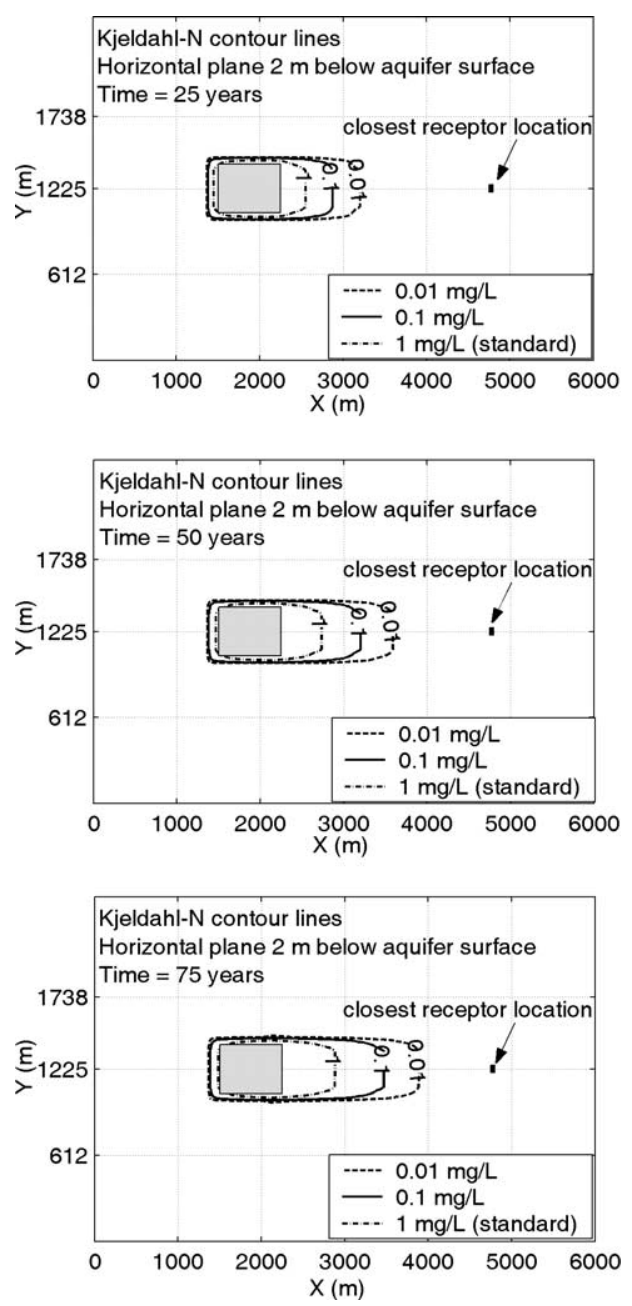

Fig. 5. Base-case simulated concentration contours of Kjeldahl-N.

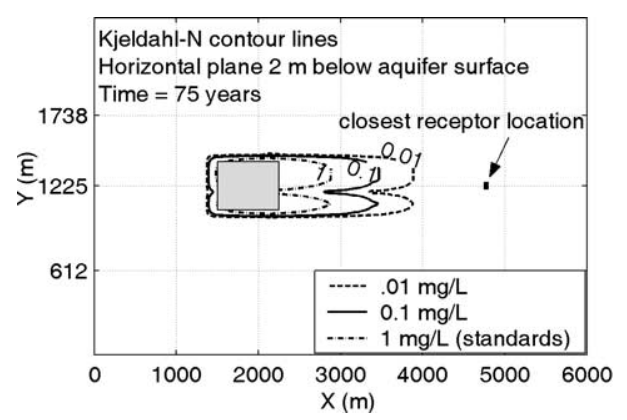

Fig. 6. Effect of fracture on simulated concentration contours of Kjeldahl-N.

standards. The simulations suggest that the contamination contributed by the landfill will not lead to groundwater concentrations exceeding local drinking water quality standards at the receptor located $2.5 \mathrm{~km}$ from the landfill. Note that these results were obtained using conservative assumptions that include no attenuation in the unsaturated zone and a relatively high contamination source strength.
What is most interesting to note in the fracture simulation is that while higher flow velocities in the fracture cause more rapid contaminant transport in this region, this higher flow also induces higher dilution such that the combined effect is a reduction in contaminant concentration (a cave in of the contours). Contaminants will be transported more rapidly and farther in the fracture; however, concentrations will be lower than concentrations in the non-fractured region.

\subsection{Sensitivity analysis}

A sensitivity analysis was conducted to assess the effect of model parameters variation on contaminant transport simulation results. The parameters evaluated and the range of values used are presented in Table 5. Variations were conducted with respect to the fractured scenario. Dispersivities in the longitudinal and transverse direction were varied simultaneously. Within the range of parameter variations, simulation results are significantly affected.

In general, model parameter variations resulted in two opposing patterns of contaminant distribution. While higher groundwater velocities increase the speed of the plume spread, they increase dilution ratio and hence tend to decrease the concentration (similar to the trends observed for the fracture). The effect of increasing dispersivities (by a factor of 50) is to enhance transport in the transverse direction, this leads to a wide but short plume as depicted in Fig. 7(a). Increasing the hydraulic conductivity of the aquifer considerably reduces contaminant concentration due to increased dilution (Fig. 7(b)). However, plume spread is faster, decreasing concentrations in the vicinity of the landfill while increasing concentrations further downstream. Considerable increase in concentration at the receptor location was detected relative to the original scenario (about a 100-fold). Similarly, Fig. 7(d) depicts the effect of increasing the fracture hydraulic conductivity by a factor of 100 , which tends to decrease concentrations in the vicinity of the site.

The temporal variation of the pollution levels is another aspect that is of significance when potential pollution from landfills is assessed. For this purpose, the effect of varying model parameters on the history of concentrations in the direct vicinity of the landfill was assessed with emphasis on compliance with drinking water standards at the border of the landfill site. Fig. 8 shows a typical concentration history pattern. In general, concentration histories near the landfill boundary depict a rise and a subsequent decay of concentrations. Contaminant levels are consistently above the drinking water standard in the area extending up to $750 \mathrm{~m}$ downstream from the landfill boundary (the boundary of the landfill property).

Highest contaminant concentrations occur when the partition coefficient is reduced to zero. However, subsequent levels fall rapidly for that case. The step change 
Table 5

Input parameter values used for the sensitivity analysis

\begin{tabular}{|c|c|c|c|c|}
\hline Parameter & Base value (BV) & Minimum value & Maximum value & Base value references \\
\hline Gradient & $0.5 \times 10^{-3}$ & - & $2 \times \mathrm{BV}$ & Site measurements by operator \\
\hline Hydraulic conductivity of aquifer & $5 \times 10^{-4}$ & $0.1 \times \mathrm{BV}$ & $10 \times \mathrm{BV}$ & Site measurements by operator \\
\hline Source strength (mg/l) & Table 4 & - & $2 \times \mathrm{BV}$ & HELP model \\
\hline Diffusivity ( $\mathrm{m}^{2} /$ year) & 0.06 & $0.02 \times \mathrm{BV}$ & $50 \times \mathrm{BV}$ & Domenico and Schwartz (1990) \\
\hline $\begin{array}{l}\text { Longitudinal dispersivity }\left(\mathrm{m}^{2} / \text { year }\right) \text {; transverse } \\
\text { dispersivity }\left(\mathrm{m}^{2} / \text { year }\right)\end{array}$ & $0.6 ; 0.06$ & $0.02 \times \mathrm{BV}$ & $50 \times \mathrm{BV}$ & Domenico and Schwartz (1990) \\
\hline Fracture width $(\mathrm{m})$ & 0.1 & \multirow{3}{*}{\multicolumn{2}{|c|}{$\begin{array}{l}0.5 \text { and } 1 \mathrm{~m} \\
100 \times \mathrm{BV} \text { and } 10,000 \times \mathrm{BV} \\
0\end{array}$}} & Assumption \\
\hline Fracture hydraulic conductivity $(\mathrm{m} / \mathrm{s})$ & $5 \times 10^{-2}$ & & & Assumption \\
\hline Partition coefficient $K_{\mathrm{d}}\left(\mathrm{m}^{3} / \mathrm{kg}\right)$ & 0.005 & & & $\begin{array}{l}\text { Site measurements by consultant/ } \\
\text { designer }\end{array}$ \\
\hline
\end{tabular}
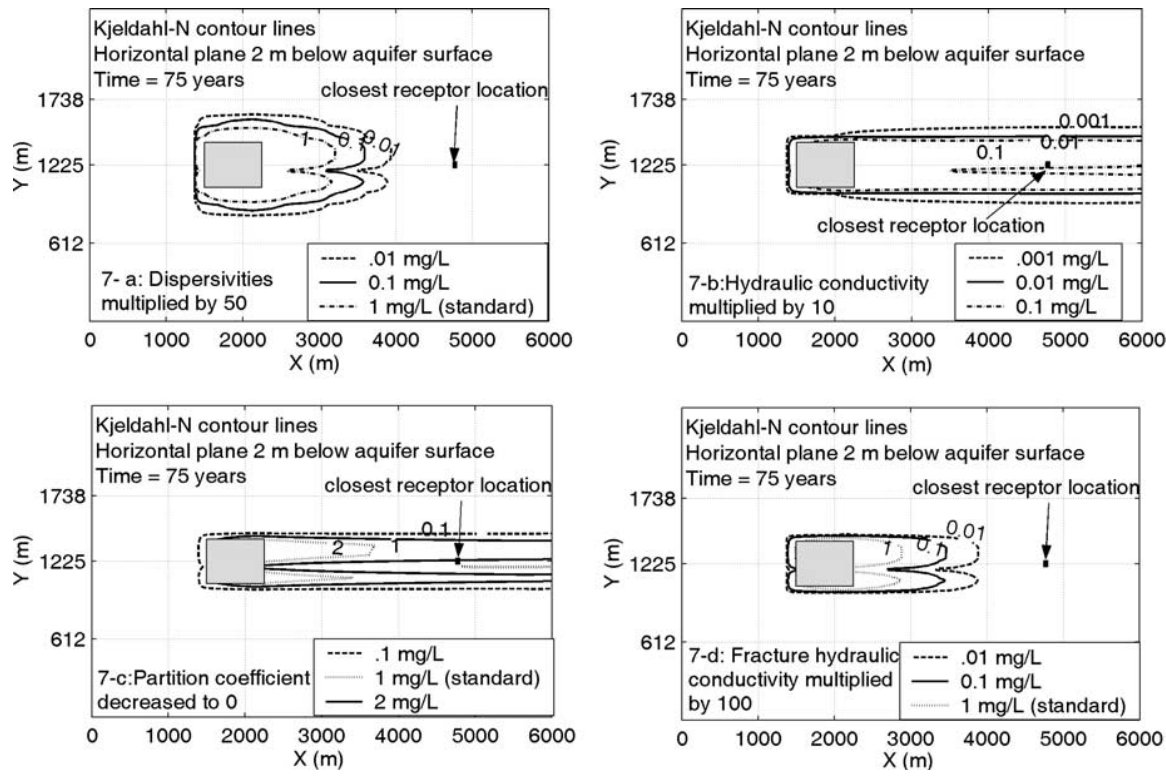

Fig. 7. Sensitivity of simulated Kjeldahl-N concentrations to changes in input parameters.

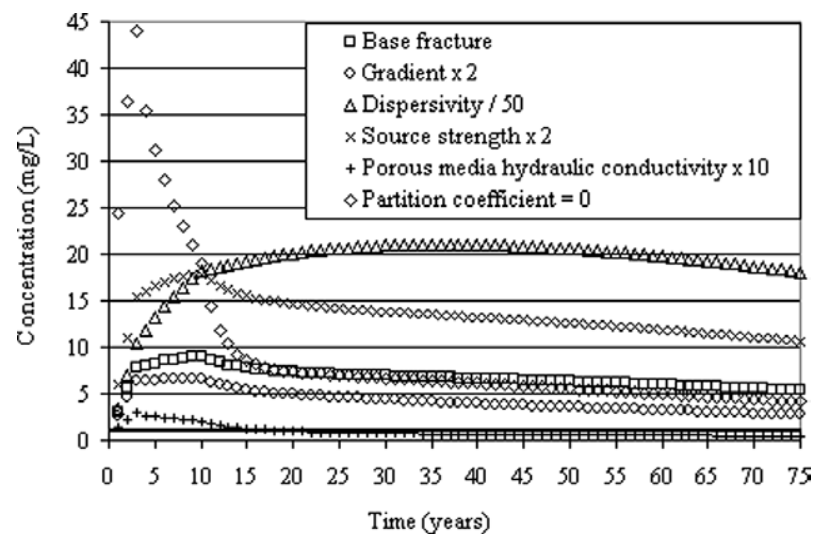

Fig. 8. Sensitivity of simulated Kjeldahl-N concentration at the border of the landfill site to changes in input parameters.

in source strength at 3 and 10 years (see Table 4) produces a rapid change in contaminant concentrations for the scenario with zero partition coefficient. Dispersivity reduction by a factor of 50 produces the second highest concentrations. However, the peak occurs 10 years after the leachate reaches the water table. Concentrations remain high during these 10 years and subsequently decrease slowly. This is due to the confinement of the plume into a narrow path as a result of low lateral dispersion. Doubling the source strength produces a predictable increase in concentrations above the base scenario. The increase in hydraulic gradient consistently reduces concentrations in the vicinity of the site due to higher velocities and dilution ratios. The effect downstream is expected to be different. Higher gradient would allow faster transport and higher concentrations downstream relative to the base scenario. The effects of higher hydraulic conductivity are similar to those of higher gradient.

\section{Discussion}

Though derived for Kjeldahl-N, the baseline and sensitivity results of this analysis would also apply to 
other pollutants for the same variation in input parameters. Sensitivity analysis simulations for iron and manganese depicted similar trends. For example, the behavior of a conservative pollutant in the subsurface is depicted in Fig. 7(c) where the partition coefficient that represents attenuation was reduced to zero.

These results suggest that the most important parameters controlling transport in the subsurface are: the hydraulic conductivity of the porous subsurface, the dispersivity of the contaminant in the subsurface, the partition coefficient representing the natural attenuation potential of the subsurface, and the presence of fractures. These parameters, along of course with source strength, should be adequately evaluated prior to initiating the simulation of contaminant transport from landfills. Field studies preceding an environmental assessment that includes analytical or numerical modeling should attempt to quantify these parameters to enhance the credibility of the modeling outcomes. In addition, the selection of the point of compliance can have a great impact on the conclusions that would be drawn from the results.

The results of the temporal pollution confirm the findings of the spatial pollution depicted by the plumes. The four important sensitivity parameters presented earlier as having the greatest impact on spatial patterns have similar impact on temporal variations. In addition, since the partition coefficient is the parameter that affects the total mass of contaminants in the groundwater, variations due to other parameters should be viewed as simply displacement of the pollution patterns in space or time. For example, while higher gradients produce lower concentrations due to higher dilution, they transport contaminants further and hence have a wider impact on groundwater quality. Similarly, low pollution levels in the vicinity of the landfill do not guarantee compliance further downstream. For example, after landfill closure the source strength might decrease to almost zero producing low concentrations at the border of the landfill property. However, patches of highly polluted groundwater formed under the landfill might move downstream displacing the peak pollution areas from the direct vicinity of the site. This scenario is more likely when the concentrations depict a quick response to the source strength (with a low partition coefficient for example).

\section{Conclusions and limitations}

The sensitivity of the model to variations in input parameters resulted in two opposing patterns of contaminant concentration. While higher groundwater velocities increase the speed of plume spread, they also increase the dilution ratio and hence decrease the concentration. The most significant changes in pollution patterns were associated with changes in dispersivities, partition coefficient, source strength, and groundwater flow velocity. The latter is mostly affected by the hydraulic conductivity of the subsurface along with the presence of fractures or variations in the gradient due to seasonal changes in the hydrologic cycle, for example. In this context, these parameters should be reasonably estimated to improve simulation results of contaminant transport. In addition, pollution patterns should be assessed spatially and temporarily. Variations in sensitivity parameters could cause displacement of the peak pollution to a different location or could delay the occurrence of the peak. Hence, it is crucial to ensure the identification of peak levels of pollution and assess compliance accordingly.

The unavailability of site-specific groundwater flow measurements to calibrate the model presents some limitations on the quality of the results. However, the availability of site specific input parameters (e.g., hydraulic conductivity, gradient and partition coefficient) and the use of the model to study the sensitivity of the output to site characteristic input parameters makes the study useful for researchers and engineers faced with similar problems and lacking extensive site specific information. The assumption of zero attenuation in the unsaturated zone is reasonable since extensive faulting and fracturing are present in the bedrock at the site; however, if the leaked leachate does not migrate through fracture networks and has to migrate through the soil matrix in parts of the unsaturated zone, significant attenuation could occur.

\section{Acknowledgements}

This study was partially funded by the Lebanese National Council for Scientific Research and the University Research Board at the American University of Beirut. Special thanks are extended to the United States Agency for International Development for its support to the Water Resources Center and the Environmental Engineering and Science Programs at the American University of Beirut.

\section{References}

Albaiges, J., Casado, F., Ventura, F., 1986. Organic indicators of groundwater pollution by a sanitary landfill. Water Research 20 , $1153-1159$.

Domenico, P.A., Schwartz, F.W., 1990. Physical and Chemical Hydrogeology. Wiley, New York.

Dunlap, W.J., Shew, D.C., Robertson, J.M., Tossaint, C.R., 1976. Organics pollutants contributed to groundwater by a landfill. In: Genetelli, E.J., Cirello, J. (Eds.), Gas and Leachate from Landfill: Formation, Collection, and Treatment. EPA-600-9-76-004.

El-Fadel, M., Findikakis, A., Leckie, J., 1997a. Environmental impacts of solid waste landfilling. Journal of Environmental Management $50(1), 1-25$. 
El-Fadel, M., Findikakis, A., Leckie, J., 1997b. Modeling leachate generation and transport an solid waste landfills. Environmental Technology 18, 669-686.

El-Fadel, M., Bou-Zeid, E., Chahine, W., Alayli, B., 2002. Temporal variation of leachate quality from pre-sorted and baled municipal solid waste with high organic and moisture content. Waste Management 22, 269-282.

Garland, G., Mosher, D., 1975. Leachate effects from improper land disposal. Waste Age 6, 42-48.

Kruempelbeck, I., Ehrig, H.J., 1999. Long-term behavior of municipal solid waste landfills in Germany. In: Christensen, T.H., Cossu, R., Stegman, R. (Eds.), Sardinia 99: Seventh Waste Management and Landfill Symposium, vol. I, 4-8 October, Cagliary, Sardinia, Italy. CISA Environmental Sanitary Engineering Center, Cagliary, 1999.

MacFarlane, D.S., Cherry, J.A., Gillham, R.W., Sudicky, E.A., 1983. Migration of contaminants in groundwater at a landfill: a case study. Journal of Hydrology 63, 1-29.

Malina, G., Szczypior, B., Ploszaj, J., Rosinska, A., 1999. Impact on ground water quality from sanitary landfills in Czestochowa region-Poland: a case study. In: Christensen, T.H., Cossu, R.,
Stegman, R. (Eds.), Sardinia 99: Seventh Waste Management and Landfill Symposium, vol IV, 4-8 October, Cagliary, Sardinia, Italy. CISA Environmental Sanitary Engineering Center, Cagliary.

Reinhard, M., Goodman, N.L., Barker, J.F., 1984. Occurrence and distribution of organic chemicals in landfill leachate plumes. Environmental Science and Technology 18, 953-961.

Runchal, A.K., Sagar, B., 1998. In: PORFLOW, a Model for Fluid Flow, Heat and Mass Transport in Multifluid, Multiphase Fractured or Porous Media. Analytic and Computational Research Inc., West Los Angeles, CA.

Schroeder, P.R., Dozier, T.S., Zappi, P.A., McEnroe, B.M., Sjostrom, J.W., Peyton, R.L., 1994. The Hydrologic Evaluation of Landfill Performance (HELP) Model: Engineering Documentation for Version 3. US Environmental Protection Agency, Office of Research and Development, Washington, DC. Report No. EPA/ 600/R-94/168b.

US EPA, 1993. Solid Waste Facility Disposal Criteria: Technical Manual. Technical Report, Office of Solid Waste and Emergency Response, Washington, DC. EPA/530-R-93-017.

Zanoni, A.E., 1972. Ground water pollution and sanitary landfills - a critical review. Ground Water 10, 3-13. 